Nowoczesne Systemy Zarządzania

Zeszyt 12 (2017), nr 1 (styczeń-marzec)

ISSN 1896-9380, s. 53-69

Modern Management Systems

Volume 12 (2017), No. 1 (January-March)

ISSN 1896-9380, pp. 53-69

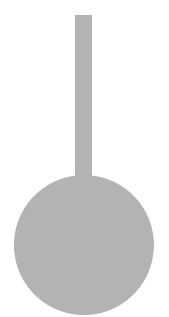

Instytut Organizacji i Zarządzania

Wydział Cybernetyki

Wojskowa Akademia Techniczna

w Warszawie

Institute of Organization and Management

Faculty of Cybernetics

Military University of Technology

\title{
Metodyki zarządzania projektami współfinansowanymi ze źródeł Europejskiego Funduszu Społecznego stosowane przez organizacje pozarządowe
}

\section{Methodology of project management co-financed from the European Social Fund sources used by non-governmental organisations}

\author{
Agnieszka Grablewska-Aagten \\ Uniwersytet Ekonomiczny w Poznaniu, Wydział Ekonomii \\ e-mail: agnieszka.grablewska-aagten@ue.poznan.pl
}

\begin{abstract}
Abstrakt: Sektor pozarządowy to jeden z głównych beneficjentów środków pomocowych z Europejskiego Funduszu Społecznego, przyznanych Polsce zarówno w obecnej, jak i poprzedniej perspektywie finansowej Unii Europejskiej. W ramach zwycięskich projektów, które uzyskały dofinansowanie z EFS, organizacje non profit muszą zdecydować, w jaki sposób chcą zarządzać swoimi przedsięwzięciami. Z pomocą przychodzą, zapożyczone z sektora biznesu, metodyki zarządzania projektami. W pracy zaprezentowano trzy - możliwe do wdrożenia głównie w projektach tradycyjnych z EFS: PRINCE2, PMBOK oraz PCM.

Prezentowany artykuł stanowi próbę wskazania metodyki - najbardziej optymalnej dla konkretnego, analizowanego podmiotu. Wybrana i zmodyfikowana do potrzeb organizacji metodyka zarządzania projektem wynika z jej problemów, zidentyfikowanych na podstawie wniosków z badania własnego, przeprowadzonego w grudniu 2015 roku w fundacji z terenu Wielkopolski, realizującej projekty ze źródełEFS. Słowa kluczowe: organizacje pozarządowe, zarządzanie projektami europejskimi, metodyki zarządzania projektem, Europejski Fundusz Społeczny
\end{abstract}

Abstract: This article presents the most common and most frequently used management practices in European Social Funds projects applied by NGO's. Indicated on different project types, carried out in the non-profit sector during the current financial period 2014-2020, a brief characterization of each of the presented practices has been elaborated. In addition, based on my own research in a foundation, which has been a financial fund ESF' beneficiary in the previous programming period, specific recommendations were formulated which also could be used for any other funding projects to achieve efficient project management. The author wants to emphasize that the indicated solutions may not be used as a general implementation tool for each organization. They are elaborated and presented for taking into consideration or - probably - for implementation. The purpose of this article is to show the availability and the 
variety of project management practices in the NGO sector so management boards will be obliged to modify existing management practices in such way they will correspond to the needs of their organizations. Keywords: non-governmental organizations, European project management, project management methodology, European Social Fund

\section{Wstęp}

Wraz z przystąpieniem Polski do struktur Unii Europejskiej, polski sektor pozarządowy zyskał niepowtarzalną szansę na rozwój i rozbudowę swojego potencjału ze źródeł zewnętrznych. Wprawdzie przed 2004 rokiem polskie organizacje pozarządowe miały możliwość skorzystania ze środków przedakcesyjnych ${ }^{1}$, jednak działania $\mathrm{i}$ ich zakres były mocno okrojone. Sytuacja zmieniła się, gdy organizacje rozpoczęły wyścig o środki z funduszy strukturalnych, w tym - nastawionego na promowanie i finansowanie działań miękkich - Europejskiego Funduszu Społecznego ${ }^{2}$.

W większości ogłaszanych konkursów, organizacje pozarządowe nie są jedynym typem beneficjenta, który może aplikować o środki z EFS. Muszą one konkurować $\mathrm{z}$ innymi podmiotami na rynku, $\mathrm{w}$ tym między innymi: przedsiębiorstwami, jednostkami sektora badawczego, uczelniami wyższymi czy instytucjami szkoleniowymi. Panująca obecnie silna rywalizacja pomiędzy sektorami: biznesu, rządowym a pozarządowym sprawiają, że NGOsy walczą i będą walczyły o możliwość skorzystania ze źródeł unijnych, a tym samym - o swoje przetrwanie. W przeciwieństwie do innych sektorów - mogą nie mieć alternatywnego źródła finansowania swych celów i zadań statutowych. Rosnąca konkurencja o klienta i świadczone przez organizacje usługi, które - jeśli są dofinansowane z EFS - będą bezpłatne dla odbiorcy, powodują, że podmioty trzeciego sektora muszą nabywać pewne cechy konkurencji. Zarządzanie projektem za pomocą różnych, dostępnych metodyk, stanowiące do niedawna domenę sektora biznesu i nauki, zostało zaimplementowane w środowisku pozarządowym.

\section{Organizacje pozarządowe jako beneficjenci Europejskiego Funduszu Społecznego}

W demokratycznym państwie prawa trudno wyobrazić sobie sprawnie funkcjonujący kraj bez społeczeństwa obywatelskiego, a tego z kolei bez dobrze rozwiniętego sektora pozarządowego. Tworzą go prywatne organizacje i instytucje non profit,

1 W okresie przedakcesyjnym Polska została objęta 3 instrumentami wsparcia finansowego Unii Europejskiej: PHARE, ISPA i SAPARD.

2 Organizacje pozarządowe świadomie włączyły się w proces przygotowawczy do absorpcji środków unijnych. Uruchomiły specjalne programy przygotowawcze, które miały na celu zwiększenie dostępu trzeciego sektora do źródeł strukturalnych oraz włączenie NGOsów w proces planowania tych funduszy. 
których celem jest działanie na rzecz dobra ogółu. Podmioty te są formą dobrowolnych stowarzyszeń, spełniających funkcje o charakterze społecznym, będąc jednocześnie poza sferą rządową i biznesu (Żyro, 2006, s.182). Ich działalność w Polsce została uregulowana Ustawą o Działalności Pożytku Publicznego i o Wolontariacie z 23 kwietnia 2003 roku, w której NGOsy zdefiniowano jako „niebędące jednostkami sektora finansów publicznych, w rozumieniu przepisów o finansach publicznych (...) i niedziałające w celu osiągnięcia zysku, osoby prawne lub jednostki nieposiadające osobowości prawnej utworzone na podstawie przepisów ustawy, w tym fundacje i stowarzyszenia" (Ustawa z dnia 24 kwietnia 2003 r. Dz.U. nr 96, poz. 873, art. 3. ust. 3).

Cechą charakterystyczną sektora non profit są oddolnie, zorganizowane w sposób spontaniczny, grupy interesów, będące skutkiem niezależnych decyzji wolnych obywateli. Istotą tych działań jest samodzielność i autonomiczność wobec struktur państwowych. Skupione w nim podmioty wypełniają lukę instytucjonalną pomiędzy państwem, rynkiem a społeczeństwem. Peter Drucker wskazuje na ich dodatkową funkcję: organizacje zapewniają porządek gospodarczy, w którym to wiedza ma kluczowy charakter, rozwiązując tym samym rozmaite kwestie porządku społecznego (Drucker, 1994, s.1). NGOsy realizują obszerny wachlarz tych usług, które - z pewnych ograniczeń technicznych, organizacyjnych i prawnych - nie mogłyby być realizowane ani przez sektor publiczny, ani prywatny.

Na rozwój sektora non profit decydujący wpływ mają ramy systemu społeczno-ekonomicznego, w jakim działa, a także nowe możliwości funkcjonowania na rynku. Jedną z bolączek polskich organizacji pozarządowych, która niemal od samego początku utrudnia ich codzienną egzystencję, jest nie najlepsza sytuacja finansowa, co przekłada się na niski potencjał finansowy, a to z kolei na trudności $\mathrm{w}$ codziennym zarządzaniu podmiotem.

Organizacje pozarządowe, składając wnioski o dofinansowanie swoich pomysłów, mogą korzystać ze źródeł krajowych, jak i zewnętrznych. W grupie tych drugich, obok tzw. Funduszy Szwajcarskich, dostępnych w ramach Grantu Blokowego Szwajcarsko-Polskiego Programu Współpracy oraz Funduszy Norweskich i EOG, czyli Norweskiego Mechanizmu Finansowego oraz Mechanizmu Finansowego Europejskiego Obszaru Gospodarczego, największym źródłem finansowania działań polskiego sektora non profit jest Unia Europejska z Europejskim Funduszem Społecznym.

EFS został powołany na mocy art. 123 Traktatu Ustanawiającego Europejską Wspólnotę Gospodarczą (eur-lex.europa.eu). W kręgu jego zainteresowań od zawsze stali ludzie. O ile w początkowym okresie głównym jego priorytetem była poprawa sytuacji na rynku pracy, to wraz z upływem czasu Fundusz zmieniał swój główny punkt zainteresowania. Byli to m.in. pracownicy niepełnosprawni, młodzież, bezrobotne kobiety, osoby chcące wrócić do pracy. Obecnie, jest on jednym $z$ wiodących instrumentów finansowych Unii Europejskiej i wspiera dążenia państw członkowskich do wysokiego poziomu zatrudnienia i wysokiej jakości miejsc pracy, a także poprawę dostępu do rynku pracy, jak również mobilność zawodową 
i geograficzną pracowników. Ułatwia im dostosowanie do zmian w przemyśle i sektorze produkcyjnym (procesy modernizacji i restrukturyzacji). Zachęca również do wysokiego poziomu kształcenia i szkolenia dla wszystkich obywateli, a także wspiera przechodzenie osób młodych z etapu kształcenia do etapu zatrudnienia. Zajmuje się zwalczaniem ubóstwa oraz wzmacnia włączenie społeczne przez aktywizację zawodową i społeczną osób zagrożonych wykluczeniem społecznym.

Beneficjentami EFS, a więc podmiotami uprawnionymi do aplikowania, są między innymi organizacje pozarządowe, które - zgodnie ze swoimi zapisami statutowymi - wpisują się w założenia konkursowe o dofinansowanie zwycięskich przedsięwzięć.

W obecnej perspektywie finansowej 2014-2020, budżet Europejskiego Funduszu Społecznego wyniósł ponad 80 mld euro, z czego Polska otrzymała kwotę ok. 13,2 mld euro (w porównaniu z poprzednią perspektywą 2007-2013 jest to o ponad 2 mld euro więcej). Środki z Europejskiego Funduszu Społecznego są wdrażane dwutorowo, tj. na poziomie krajowym w ramach Programu Operacyjnego Wiedza Edukacja Rozwój ( $\mathrm{z}$ budżetem 4,4 mld euro) i regionalnym (łączny budżet to 8,8 mld euro) (funduszeeuropejskie,gov.pl, 2015), w ramach 16 regionalnych programów operacyjnych, odrębnych dla każdego województwa.

Z badania przeprowadzonego w 2006 roku przez Stowarzyszenie Klon/Jawor wynika, że w ciągu dwóch lat w perspektywie 2004-2006 po dofinansowanie ze środków unijnych aplikowało zaledwie $9 \%$ wszystkich organizacji, z czego skutecznie zrobiło to ok. 30\%, awięc dofinansowanie z tego źródła otrzymało zaledwie ok. 3\% wszystkich podmiotów (Gumkowska, Herbst, 2006, s. 50). Dla porównania, to samo pytanie zadano organizacjom w 2015 roku przez to samo stowarzyszenie: aż 37\% podmiotów non profit przynajmniej raz w poprzedniej perspektywie finansowej 2007-2013 próbowało zdobyć środki z EFS. Proces aplikacyjny zakończył się dofinansowaniem co najmniej 1 projektu w przypadku aż 64\% wnioskujących. Oznacza to, że 23\% organizacji aktywnych w 2015 roku skorzystało przynajmniej raz ze środków UE w latach 2007-2014 (Adamiak, Charycka, Gumkowska, 2016, s. 77). Coraz bardziej widoczny staje się proces specjalizacji organizacji w kontekście aplikowania, a co za tym idzie - również zarządzania projektami.

Wachlarz projektów, ze względu na ich problematykę i grupę docelową, jest dość szeroki, jednak na potrzeby niniejszego artykułu zostanie dokonany następujący podział na projekty współfinansowane ze źródeł Europejskiego Funduszu Społecznego:

- projekty tradycyjne, skierowane do grupy docelowej, znajdującej się w trudnej sytuacji na rynku pracy;

- projekty zakładające innowacje społeczne (w fazach testowania i upowszechniania) ${ }^{3}$;

3 Celem projektów testujących jest wypracowanie nowych rozwiązań oraz ich upowszechnienie i włączenie do głównego nurtu polityki sektorowej. Z kolei projekty upowszechniające to takie, które koncentrują się na promocji zastosowania nowych, już istniejących, produktów oraz na działaniach, związanych z ich szerszym wykorzystaniem w danej polityce. 
- projekty badawczo-rozwojowe, w których organizacje non profit występują częściej w konsorcjum lub w roli partnera.

Projekty tradycyjne, współfinansowane ze źródeł EFS, stanowią najczęstszą formę dotowanych przedsięwzięć. W grupie tej, spotykamy projekty edukacyjne (zarówno dla dzieci, młodzieży, jak i osób dorosłych), szkoleniowe, zakładające aktywizację zawodową i społeczną osób wykluczonych lub zagrożonych wykluczeniem społecznym, promujące przedsiębiorczość, a także takie, których celem jest poprawa sytuacji na rynku pracy. Takie projekty - z uwagi na swój najmniej (na tle pozostałych) skomplikowany charakter - realizowane są najchętniej i najczęściej przez organizacje pozarządowe. Odsetek projektów niezakończonych lub takich, $\mathrm{w}$ których umowa została rozwiązana $\mathrm{z}$ beneficjentem przed czasem - w tej grupie projektów - jest niewielki, co nie znaczy, że w ogóle nie istnieje. Druga grupa projektów to takie, w których - w ramach obszarów tematycznych EFS - poszukuje się lepszych sposobów rozwiązania istniejących problemów lub nowych form działań dla problemów już istniejących, tak, aby zniwelować ich skutki. W trzeciej grupie znajdą się projekty z pogranicza nauki i biznesu, których celem jest transfer wyników badań z nauki do biznesu i na odwrót.

\section{Metodyki zarządzania projektami}

Na potrzeby niniejszego artykułu, przyjęto definicję projektu jako „niepowtarzalnego, złożonego przedsięwzięcia, zawartego w skończonym przedziale czasowym, $\mathrm{z}$ wyróżnionym początkiem i końcem, realizowanego zespołowo, w sposób względnie niezależny od powtarzalnej działalności, z zastosowaniem specjalnych metod oraz technik", zaproponowaną przez M. Trockiego (Trocki, Grucza, Ogonek, 2003, s.17-18). Wskazuje ona na powtarzalne cechy, jakimi charakteryzuje się projekt, czyli: 1) orientacja na wcześniej określony cel, 2) unikalny, niepowtarzalny charakter, 3) kompleksowość, 4) założone zasoby, 5) określone z góry ramy czasowe, tj. projekt ma swój początek i koniec. Z kolei zarządzanie projektem to spełnienie lub przekroczenie wymagań i potrzeb odbiorców projektu, przy zastosowaniu wiedzy, umiejętności, technik i narzędzi w działaniach w danym przedsięwzięciu (A Guide to the Project Management Body of Knowledge, 2012, s. 5-6). Jest nim też zastosowanie dostępnej wiedzy, umiejętności, narzędzi i metod dla osiągnięcia celów projektu, przy czym wskazuje na warunek uzyskania założonych rezultatów w wyznaczonym czasie i limicie kosztów (Trocki, 2015, s. 121) przez „, harmonizację współdziałania uczestników i innych interesariuszy projektu" (Trocki, 2015, s. 121). Powyższe definicje wskazują na osiągnięcie celów i wskaźników rezultatów projektowych przy podstawowych ograniczeniach, jak z góry określony czas i budżet, przy 
czym należy wziąć pod uwagę dodatkowe zmienne, jak zasoby projektu i jakość, tj. czy beneficjenci projektu są zadowoleni ${ }^{4}$ (A. Szpitler, 2014, s. 15).

Zarządzanie projektem opiera się na założeniu, że projekt ma charakter cykliczny; stanowi zamkniętą całość i składa się z powtarzalnych etapów i faz (Trocki, 2015, s. 121). Przy czym, o ile wśród badaczy istnieje zgodność co do cyklicznego charakteru projektu, to już brak jej w przypadku ilości, kolejności i rodzaju składających się nań faz i etapów.

Niniejsza praca koncentruje się na stosowanych metodykach zarządzania projektem, rozumianych jako całościowe postępowanie, którego celem jest tworzenie koncepcji „technologii” rozwiązania określonych zadań, zawierającej charakterystykę obszaru badań, ich bazowy plan, schemat procesu badawczego, wskazania badawcze i dyspozycję opracowania badawczego (Stabryła, Trzcieniecki, 1988, s. 61). Metodyka to „zbiór procesów i reguł, które organizacja zaleca lub nakazuje stosować kierownikowi projektu (...), dzięki czemu ma ona pewność, że wszystkie realizowane przez nią projekty będą zarządzane w sposób spójny" (Nicholas, Steyn, 2012, s. 805-806). Metodyka stanowi zatem uszczegółowienie metody, definiowanej jako systematyczny sposób postępowania (skład i układ jego stadiów), gdzie „na wysokim stopniu uogólnienia metoda bliska jest pojęciu zasady” (Martyniak, 1999, s. 7). Warto zaznaczyć, że stosowanie konkretnej metody nie wyklucza zastosowania bardziej szczegółowej metodyki zarządzania, która będzie tę pierwszą uzupełniała. Dlatego większość projektów tradycyjnych z EFS będzie zarządzana właśnie zgodnie z metodą tradycyjną ${ }^{5}$ (Wysocki, 2013, s. 84-85), a wdrożenie odpowiedniej metodyki zwiększa szanse na realizację przedsięwzięcia, zakończonego sukcesem.

W ramach zrządzania projektami powstało wiele metodyk, opisujących w sposób szczegółowy poszczególne etapy w fazach planowania i realizacji projektu. Jednak niektóre projekty, realizowane przez sektor NGO, kończą się z uznaniem części (a czasem całości) kosztów za niekwalifikowane. Rodzi się pytanie o technikę, jaką zarządzany jest projekt i zasadność jej wyboru. Z jednej strony metodyka - w przypadku projektów unijnych - wydaje się być narzucona przez grantodawcę. $Z$ drugiej zaś, projektodawca powinien mieć możliwość jej wyboru, np.: spośród już istniejących. Stanowi to punkt wyjścia i bazę, na której organizacja tworzy własną metodykę, dostosowaną do swoich potrzeb, praktyk i wewnętrznych procedur. Jedne z nich są uniwersalne, dzięki czemu można je z powodzeniem stosować przez podmioty różnego typu w wielu sektorach gospodarki. Do najczęściej stosowanych (w ramach modelu tradycyjnego) metodyk zarządzania, należą: PRojects IN Controlled

$4 \quad$ Tzw. trójkąt ograniczeń projektu ukazuje wzajemne zależności pomiędzy poszczególnymi elementami, choć zmienna zasobów jest traktowana jako dodatkowa w literaturze przedmiotu.

5 W sposób dość ogólny, w ramach opracowanego Modelu Cyklu Zarządzania Projektem (PMLC), na który składają się procesy: definiowania zakresu, planowania, wykonania, monitoringu i kontroli, a także zamknięcie projektu, R. K. Wysocki wyróżnił 3 modele (metody) zarządzania projektami: tradycyjny (w tym: liniowy i stopniowy), zwinny (w tym: iteracyjny i adaptacyjny) oraz ekstremalny. 


\section{Environments (PRINCE2), Project Management Body Of Knowledge (PMBOK) oraz Project Cycle Management (PCM).}

Pierwsza z nich - PRINCE2, narodziła się pod koniec lat 80-tych w Wielkiej Brytanii ${ }^{6}$ i tam stała się obowiązującym standardem zarządzania projektami (pod red. Janasza, Wiśniewskiej, 2014, s.155). Doczekała się dwóch wersji, z czego ostatnia pochodzi z 2009 roku. Stanowi zbiór najlepszych praktyk zarządzania projektami informatycznymi ${ }^{7}$, który jest stosowany również w Australii oraz Holandii. Do procesów, wyszczególnionych w ramach tej metodyki, zaliczamy:

1) Przygotowanie założeń projektu

2) Zarządzanie strategiczne projektem - właścicielem procesu jest - wybrany przez wyższe kierownictwo organizacji - Komitet Sterujacy (KS), który na tym etapie angażuje się tylko w granicach etapów zarządczych, w których decyduje, czy można kontynuować prace i przejść do następnego etapu: tzw. podprocesy zezwolenia. Co ważne, KS kieruje się zasadą zarządzania przez wyjątki: podejmuje decyzje w projekcie wyłącznie wówczas, gdy uzyska informację, że pojawily się pewne odchylenia w realizacji projektu, wychodzące poza akceptowalne granice. W komitecie zasiadają: przewodniczący KS, główny użytkownik oraz główny dostawca, a każdy z nich reprezentuje odmienne grupy interesariuszy (Trocki, 2015, s. 320-322)

6 Powstała ona w 1989 roku w rządowej Central Computer Communications Agency na bazie metodyki PROMPT.

7 Główne założenia PRINCE2, to między innymi:

- $\quad$ projekt musi być zarządzany tak, aby zakończył się sukcesem;

- przedsięwzięcie musi posiadać określony początek i koniec;

- zarówno strona finansująca, jak zarządzająca i pracownicy muszą mieć dokładnie określone swoje cele oraz kompetencje;

- przedsięwzięcie musi mieć uzasadnienie biznesowe, w tym określone ryzyko i korzyści, związane z jego realizacją;

- projekt powinien charakteryzować się niepowtarzalnym zestawem produktów ogólnych i cząstkowych;

- $\quad$ zakres prowadzonych działań w projekcie powinien być adekwatny do oczekiwanych produktów/rezultatów;

- $\quad$ projekt powinien określić zasoby, niezbędne do wykonania działań w danym zakresie;

- $\quad$ projekt powinien zawierać szereg procesów i związanych z nimi technik.

8 Poprzedza projekt, a jego celem jest przygotowanie przedsięwzięcia do uruchomienia.

9 Przewodniczący KS działa jako sponsor przedsięwzięcia i jest całkowicie odpowiedzialny za jego sukces. Równoważy także interesy każdej z grup: biznesu, dostawców i użytkowników. Z kolei główny użytkownik (jako reprezentant tych, których cele ma realizować przedsięwzięcie i użytkowników, którzy mają posługiwać się wytworzonymi produktami w ramach projektu) ma za zadanie zapewnienie jasnych, zrozumiałych wytycznych i ich przestrzeganie w trakcie realizacji projektu. Do zadań głównego dostawcy (działającego w interesie wykonawców, zleceniobiorców, a także osób tworzących i wdrażających wytworzone w projekcie produkty) należy opracowanie - możliwych do osiągnięcia - wymagań oraz założeń, a następnie ich realizację w ramach posiadanych zasobów. 
3) Inicjowanie projektu ${ }^{10}$;

4) Sterowanie etapem (zarządzanie przez kierownika projektu);

5) Zarzadzanie wytwarzaniem produktów $w^{11}$;

6) Zarzadzanie zakresem etapu ${ }^{12}$;

7) Zamykanie projektu.

Każdy projekt jest dzielony na odpowiednią ilość etapów, przy czym zgodnie z PRINCE2 musi zawierać co najmniej 2 etapy zarządcze: inicjowanie projektu oraz realizację projektu. Procesy 1), 3) i 7) to jednocześnie określone fazy cyklu życia projektu. Na etapie realizacji projektu mamy do czynienia z procesami: 4), 5) oraz 6). Co ważne, proces Strategiczne zarządzanie projektem obejmuje cały cykl życia projektu, natomiast proces Planowania jest aktywny we wszystkich fazach przedsięwzięcia, $\mathrm{z}$ wyjątkiem ostatniego - 7). Zgodnie z zasadami PRINCE2, aby móc przejść do kolejnego etapu, każdy bieżący musi zostać ukończony, a następnie zaakceptowany przez Komitet Sterujący.

$\mathrm{W}$ ramach podprocesów wyróżniamy 40 działań, gdzie każde z nich zawiera rekomendowane czynności oraz dokładne zestawienie obowiązków. Stosowane techniki nie są niczym innym jak instrukcjami postępowania, dzięki którym w wyżej opisanych procesach wykorzystywane lub wytwarzane są produkty specjalistyczne i zarządcze.

Pryncypia PRINCE2 ${ }^{13}$ stanowią naczelne nakazy dla wszystkich projektów, zarządzanych zgodnie z metodyką PRINCE2 ${ }^{14} / 15$. Metodyka ta zakłada osiem ról ${ }^{16}$, dla każdej wskazując konkretne kompetencje ${ }^{17}$. Zdaniem M. Trockiego zasady, proponowane i opisane w metodyce PRINCE2, niewątpliwie należą „do najlepszych standardów struktur organizacyjnych w zarządzaniu projektami, w tym ze źródeł EFS. Dostarcza ona nie tylko szczegółową strukturę oraz podział ról projektowych, wraz z zakresem przypisanych im celów i zadań, ale przede wszystkim różne punkty widzenia" (Trocki, 2015, s. 320).

10 Ma na celu opracowanie solidnych podstaw dla przedsięwzięcia, a każda z osób zaangażowana w realizację projektu powinna mieć ściśle przypisane cele, zadania i funkcje w projekcie. W tym procesie wytwarzane są produkty, dla których uzyskania uruchomiono projekt. Daje informacje, czy wszystkie produkty założone w projekcie zostały wytworzone i czy nie powstały żadne odchylenia od pierwotnych założeń. Pryncypia PRINCE2 to: 1. Ciągła zasadność biznesowa; 2. Korzystanie z doświadczeń; 3. Zdefiniowane role i obowiązki; 4. Zarządzanie etapowe; 5. Zarządzanie z wykorzystaniem tolerancji; 6. Koncentracja na produktach; 7. Dostosowanie do warunków projektu Zgodnie z powyższym założeniem, jeśli projekt nie spełnia jednej z zasad, nie można wówczas mówić o zarządzaniu projektem zgodnie $\mathrm{z}$ tą metodyką. What is PRINCE2? https://www.prince2.com/eur/what-is-prince2 (26.11.2016). Komitet Sterujący, Przewodniczący, Główny Użytkownik, Główny Dostawca, Kierownik Projektu, Kierownik Zespołu, Nadzór Projektu oraz Wsparcie Projektu. 
Kolejną, należącą do uniwersalnych metodyk zarządzania projektem, jest PMBOK, choć tak naprawdę stanowi ona zbiór standardów i dobrych praktyk $\mathrm{w}$ dziedzinie zarządzania projektami ${ }^{18}$, opracowanymi i opublikowanymi przez członków Project Management Institute ${ }^{19}$. Standard PMBOK ${ }^{20}$ jest aktualizowany co cztery lata, a ostatnio obowiązująca wersja pochodzi z grudnia 2012 roku (A Guide to the Project Management Body Of Knowledge, 2012). Metodyka ta opiera się na produktach, a pracę definiuje jako wynik poszczególnych procesów, zachodzących w projekcie. Aktualną wersję PMBOK wyróżnia dziesięć obszarów wiedzy, w ramach których zakłada się przygotowanie konkretnych rozwiązań: 1. Integracja, 2. Zakres, 3. Czas, 4. Koszt, 5. Jakość, 6. Zasoby ludzkie, 7. Komunikacja, 8. Ryzyko, 9. Zamówienia oraz 10. Interesariusze ${ }^{21}$.

W każdym z obszarów należy uruchomić odpowiednie rodzaje procesów, tak, aby zakończyć projekt sukcesem. Wśród 47 procesów wyszczególnionych w Guide to PMBOK, wskazuje się 5 grup, złożonych z procesów: rozpoczęcia, planowania, realizacji, kontroli oraz zakończenia przedsięwzięcia. Procesy mogą nachodzić na siebie w czasie realizacji projektu lub jego fazy, a do obowiązków kierownika projektu należy odpowiedni dobór procesów, adekwatnych dla konkretnego projektu (pod red. Janasza, Wiśniewskiej, 2014, s.164). W ramach każdego przenikającego się procesu oraz obszaru powinno - zgodne z zaleceniami metodyki PMBOK - powstać konkretne rozwiązanie, zapewniające sprawną realizację projektu. Kolejne fazy i ich produkty składają się na całościowy cykl życia projektu ${ }^{22}$.

Ostatnia z omawianych - Project Cycle Management (PCM) - to metodyka zarządzania cyklem projektu, zwana również europejską metodyką zarządzania projektami. Została przyjęta do stosowania przez Komisję Europejską w 1992 roku jako standard zarządzania projektami, finansowanymi ze źródeł europejskich. Stanowi odpowiedź na konieczność stworzenia metodycznych rozwiązań, usprawniających zarządzanie zarówno ze strony KE jako sponsora, jak również beneficjentów i wykonawców $\mathrm{w}$ projektach unijnych. Opiera się na prostym modelu, który - w ograniczeniach

18 Choć PMBOK nie jest metodyką, a zbiorem najlepszych, powszechnie uznawanych praktyk, to za taką ją uznano.

19 PMI powstał w 1969 roku. PMBOK Guide został opublikowany przez PMI w roku 1983 w formie białej księgi jako próba udokumentowania i standaryzacji ogólnie przyjętych praktyk, dotyczących zarządzania projektami.

20 Podobnie, jak PRINCE2 w Wielkiej Brytanii, tak PMBOK Guide został zatwierdzony przez American National Standards Institute jako obowiązujący standard zarządzania projektami w Stanach Zjednoczonych

21 Ostatni z obszarów - Zarządzanie interesariuszami - został dodany w 2012 roku i obejmuje procesy: identyfikacji, planowania zarządzaniem, zarządzanie zaangażowaniem oraz kontrolę zaangażowania interesariuszy.

22 Zgodnie z A Guide to the PMBOK, każde przedsięwzięcie składa się z etapów, zaś każdy etap posiada swoje wejście oraz wyjście. Produkty, będące rezultatem na wyjściu jednego etapu projektu, stanowią jednocześnie elementy na wejściu dla następnego etapu. 
czasowych i finansowych - pozwala na jasne sprecyzowanie celów, zadań, a następnie efektów przy jednoczesnym minimalizowaniu ryzyka ${ }^{23}$. Narzędzie to ma zapewniać skuteczność w osiąganiu założonych celów zgodnie z metodą SMART (Specific, czyli konkretne; Measurable - mierzalne; Achievable - osiaggalne; Realistic - realne oraz Time-bound - określone w czasie), weryfikowanych na podstawie przyjętych przez beneficjentów wskaźników rezultatów, produktów czy efektów. Choć Unia Europejska nie narzuca swym projektodawcom konkretnej metodyki wspierającej zarządzanie projektami, to jednak przedsięwzięcia, zarządzane, zgodnie z metodyką PCM, są wyżej punktowane. Przygotowanie wniosku, zgodnie ze szczegółowo określonymi zasadami metodycznymi, ma bowiem zmniejszyć ryzyko niepowodzenia projektu i zapewnić celowość przekazanych dotacji. PCM opiera się na następujących zasadach:

1. zastosowanie narzędzi do zarządzania (planowania projektu) ${ }^{24}$,

2. standaryzacja dokumentó $\mathbf{w}^{25}$,

3. konsultacje $\mathrm{e}^{26}$,

4. transparentny cel SMART oraz

5. jakość ${ }^{27}$.

Metodyka PCM wyróżnia pięć, podstawowych faz cyklu: 1) Programowanie, 2) Identyfikacja, 3)Formułowanie, 4) Wdrażanie i monitorowanie oraz 5) Ewolucja i audyt projektów. Fazy cyklu projektu następują po sobie, a każda faza prowadzi do następnej (Trocki, Grucza, 2007, s. 35-37).

Głównym narzędziem, służącym do projektowania i zarządzania projektem wg PCM jest podejście oparte na matrycy logicznej: Logical Framework Approach (Zarządzanie cyklem projektu, 2006, s. 10-14). Podejście to pozwala na identyfikację i analizę problemów oraz definiowanie działań, które należy podjąć, by problemy zostały rozwiązane, a wyznaczone cele - osiągnięte ${ }^{28}$. Przygotowanie matrycy logicznej składa się z etapu analizy oraz etapu planowania, z czego etap analizy przeprowadza się na czterech płaszczyznach: interesariuszy, problemów, celów oraz strategii (Zarządzanie cyklem..., 2006, s. 9). Z kolei na fazę planowania składa się: budowa matrycy logicznej

23 Stworzony w ramach PCM schemat metodyczny pozwala zidentyfikować, a następnie opisać istniejące problemy. W odpowiedzi na nie tworzy, planuje, wdraża, a następnie monitoruje i ocenia się działania, które miały rozwiązać lub zniwelować owe problemy.

Użycie matrycy logicznej do analizowania i przygotowania odpowiednich rozwiązań.

Przygotowanie w każdej z faz realizacji projektu dokumentów o dobrej jakości. i bezpośrednich), którzy będą mogli wykorzystywać rezultaty projektu.

Włączenie czwartego elementu do środka trójkąta projektu, gdzie wpływ na nią ma każda zmiana dowolnej ze stron.

Struktura ramy logicznej pozwala na weryfikację proponowanego przedsięwzięcia pod kątem jego trafności, trwałości i wykonalności. Opracowana na etapie przygotowania i planowania projektu jest kluczowym narzędziem zarządzania projektem, również na etapie jego wdrażania oraz ewaluacji. Matryca logiczna charakteryzuje się tzw. elementem przyczynowo-skutkowym, który występuje między poszczególnymi poziomami celów, rezultatów, produktów i działań. 
(jako dokumentu zawierającego podstawowe informacje o celach i strukturze projektu), tworzenie harmonogramu, (ilustrującego przebieg projektu w czasie), a także planowanie zasobów i kosztów, umieszczanych razem w budżecie projektowym.

Należy jednak zwrócić uwagę na fakt, że z punktu widzenia Komisji Europejskiej jako sponsora, dość rozbudowana została faza inicjowania i definiowania projektu, co daje podstawę do wyboru najlepiej rokujących przedsięwzięć do dofinansowania. $\mathrm{Z}$ kolei fazy planowania i sterowania projektem zostały potraktowane $\mathrm{w}$ sposób ogólnikowy. Taki brak równowagi w zarządzaniu poszczególnymi fazami może prowadzić do sytuacji, w której beneficjenci środków unijnych wiedzą, jak aplikować o dotację na projekt, jednak mogą mieć problemy z jego realizacją.

\subsection{Wybór metodyki}

W zależności od specyfiki projektu, jak również typu organizacji, która go realizuje, wybiera się, a następnie stosuje różnorodne metody bądź metodyki zarządzania projektem. W przypadku projektów innowacyjnych i badawaczo-rozwojowych ${ }^{29}$, wybór metodyki wydaje się być prostszy ${ }^{30}$. Przy tak wysokim stopniu niepewności w odniesieniu do efektów i rezultatów, w tym innowacyjnego produktu finalnego, zastosowanie zwinnego modelu zarządzania projektem lub należącą do zwinnych praktyk zarządzania: Agile Project Management ${ }^{31}$ - wydaje się być warunkiem koniecznym (Projekty innowacyjne. Poradnik dla projektodawców PO KL, 2011, s. 26-28).

29 Organizacje bardzo rzadko decydują się na zarządzanie zgodnie z modelem ekstremalnym. Wyjątek mogą stanowić pojedyncze NGOsy, wyspecjalizowane, posiadające wiedzę ekspercką i stale współpracujące $\mathrm{z}$ jednostkami naukowo-badawczymi (w projektach zakłada się transfer technologii z wiedzy do przemysłu - projekty ze sfery $\mathrm{B}+\mathrm{R}$ ).

W nich organizacje nie zastosują zarządzania ekstremalnego (bo cele projektu są znane), ale też nie tradycyjnego, które nie dostosuje się do dynamicznie zmieniającego się otoczenia. Celem projektów innowacyjnych z POWER - podobnie, jak wcześniej z PO KL - jest wypracowanie i przetestowanie innowacji społecznej (na poziomie problemu, uczestników lub instrumentów wsparcia) jako rozwiązania istniejących problemów w jednym z obszarów tematycznych EFS. Przedsięwzięcia ukierunkowane na wdrażanie innowacji wymagają odmiennego podejścia, szczególnie, jeżeli chodzi o fazę realizacji projektu.

31 Kraszewska M., 2013, Zwinne metodyki zarzadzania projektami http://www.ipma.pl/ informacje-prasowe/zwinne-metodyki-zarzadzania-projektami_n2050(10.09.2013) Agile Project Management (APM) jest zestawem założeń i metodyk, którego fundamenty opracowano już w 2001 roku w odpowiedzi na potrzebę realizacji projektów w warunkach większej niepewności. W APM przyjmuje się, że projekt zostaje rozbity na małe, zarządzane jednostki działania, zwane „iteracjami”. Po zakończeniu każdej iteracji ma pojawić się rozwiązanie. Zakłada się przy tym, że mogą pojawić się zmiany oraz zakłócenia. Jednak podział projektu na małe jednostki działania (czyli iteracje) ma umożliwić ustalenie priorytetów co do wyników, a następnie - osiągnięcie ich. Podział projektu na małe jednostki działania umożliwia wprowadzanie zmian, dodawanie, przedefiniowanie, co w dużych - z góry zaplanowanych przedsięwzięciach - jest niemożliwe, gdyż wpływałoby silnie na samą konstrukcję rozwiązania, jak i dalszą realizację projektu. 
$\mathrm{Z}$ uwagi na niewielki odsetek przedsięwzięć $\mathrm{z}$ EFS, realizowanych przez sektor pozarządowy, w których można by z sukcesem zastosować tę metodykę zarządzania projektem, niniejszy artykuł jedynie sygnalizuje ją jako stosowaną w projektach innowacyjnych i badawczo - rozwojowych. Tym samym autorka ograniczy się do tych metodyk zarządzania projektami, które są - jej zdaniem - możliwe do implementacji w większości projektów, zarządzanych zgodnie z modelem tradycyjnym.

Największą grupę projektów stanowią przedsięwzięcia, w których stopień niepewności i ryzyka projektowego jest dość niski. To w nich, projektodawcy wywodzący się z sektora pozarządowego, stosują przeważnie tradycyjne podejście w zarządzaniu projektami oraz metodykę PCM. Wynika to z zaleceń Komisji Europejskiej na poziomie unijnym oraz - na szczeblu krajowym - Instytucji Zarządzających poszczególnymi Programami Operacyjnymi. Z drugiej strony, organizacje pozarządowe mają ograniczoną wiedzę $\mathrm{w}$ dziedzinie zarządzania projektami $\mathrm{i}$ - w obawie przed błędnym wyborem - nie dokonują samodzielnego doboru metodyki, ani też nie modyfikują jej do swoich potrzeb. W przypadku przedsięwzięć małych, o niewielkim stopniu skomplikowania, krótkim harmonogramie i budżecie kilkudziesięciu tysięcy złotych, zastosowanie metodyki PCM w projekcie, współfinansowanym ze źródeł EFS, wydaje się być wystarczające, a jej rozbudowywanie przewyższałoby posiadane zasoby.

Inaczej wygląda sytuacja w projektach - choć z pozoru tradycyjnych - to zarządzanych w okresie wieloletnim, o złożonym zakresie i harmonogramie działań lub $\mathrm{z}$ budżetem projektu przekraczającym wartość kilkuset tysięcy złotych. Powyższa sytuacja komplikuje się, gdy organizacja wygrywa kilka konkursów i realizuje równocześnie 2 i więcej projektów z EFS. Przyjęcie jednej z wyżej przedstawionych metodyk, bez ich wcześniejszej modyfikacji, może doprowadzić do sytuacji, w której zarządzanie projektem będzie łatwe jedynie na papierze, a rzeczywistość może przerosnąć członków zespołu projektowego.

\section{Badanie organizacji pozarządowej jako projektodawcy ze źródeł Europejskiego Funduszu Społecznego}

W grudniu 2015 roku przeprowadzono analizę ex-post trzech losowo wybranych projektów, zrealizowanych i zakończonych w terminie do 30 czerwca 2015 roku przez jedną z poznańskich fundacji. Wszystkie projekty były realizowane w ramach Programu Operacyjnego Kapitał Ludzki 2007-2013 ze źródeł EFS w ramach tej samej osi priorytetowej: VII Promocja integracji społecznej, przy czym każdy z nich był realizowany w innym województwie.

Celem głównym każdego z przedsięwzięć była aktywizacja zawodowa i społeczna osób zagrożonych wykluczeniem, w tym osób z niepełnosprawnością. Cel powyższy miał być osiągnięty poprzez zastosowanie indywidualnego planu działania 
dla każdego z uczestników projektu, który określał, w jakich formach wsparcia interesariusz mógł wziąć udział ${ }^{32}$. Sukces projektu był tym większy, im więcej uczestników projektu - na jego zakończenie - znalazło zatrudnienie na okres co najmniej 3 miesięcy.

Badanie miało dwojaki charakter: analiza dokumentacji projektowej ex post na zakończenie projektu oraz wywiad indywidualny z koordynatorami wylosowanych trzech projektów. Kontrola wybranych dokumentacji ograniczyła się do podstawowych parametrów projektu i jego ewentualnych odchyleń, takich jak: budżet, harmonogram, wskaźniki (rezultatów, produktów i efektów) oraz uczestnicy projektu. W końcowych wnioskach o płatność dla każdego z 3 projektów, fundacja rozliczyła się z przekazanych środków i wskazała na osiągnięcie wszystkich założonych celów i ich wskaźników. Ewaluacja dokumentacji, opracowanych przez psychologa i doradcę zawodowego, wskazała m.in. na wzrost wiary we własne siły oraz nabycie wiedzy i umiejętności do aktywnego poszukiwania pracy przez uczestników. Zgodnie $\mathrm{z}$ dokumentacją projektu i zapisami w pkt 3.7 wniosku o dofinansowanie, projekt zarządzany był zgodnie z metodyką PCM. Na podstawie przedstawionej dokumentacji nie stwierdzono żadnych odchyleń od pierwotnych założeń projektu. Nie wynikało również z niej, aby w projekcie pojawiły się jakiekolwiek problemy w jego realizacji.

Nowe światło na realizację każdego z przedsięwzięć rzuciły wywiady z kierownikami projektów. Choć każdy z nich realizował odrębny projekt i miał inne doświadczenie $\mathrm{w}$ stosunku do pozostałych pracowników, to ich spostrzeżenia były podobne, a każdy z nich napotkał na co najmniej na dwa, powtarzające się na etapie realizacji projektu, problemy:

1. brak natychmiastowego wsparcia ze strony kierownictwa fundacji w przypadku pojawienia się problemów,

2. brak wystarczającej liczby chętnych do uczestnictwa w projekcie.

Badani koordynatorzy zgodzili się jednomyślnie, że informowali swoich przełożonych o problemach w projekcie dopiero w przypadku wystąpienia ryzyka, tj. sytuacji zagrażającej jego dalszej realizacji. Pozostawiona kierownikom projektu szeroka swoboda działania spowodowała, że nierzadko ani oni, ani reszta zespołu projektowego nie zdawali sobie sprawy z zagrożenia, jakie niesie za sobą podejmowana decyzja lub jej brak. To z kolei rzutowało na opóźnienia w projekcie z uwagi na czas, jaki był niezbędny, aby zarząd mógł przedsięwziąć nadzwyczajne środki naprawcze na danym etapie projektu. Sytuacja taka miała miejsce w każdym $\mathrm{z}$ badanych projektów. Równocześnie należy wspomnieć, że we wspomnianym okresie, fundacja realizowała 12 projektów współfinansowanych ze źródeł EFS. Nie stosując żadnych rozwiązań w zarządzaniu projektami, kierownictwo organizacji było postawione

32 W ramach Indywidualnych Planów Działania realizowane były: poradnictwo zawodowe (indywidualne i grupowe), poradnictwo psychologiczne (indywidualne i grupowe), kursy i szkolenia zawodowe, płatne staże zawodowe oraz pośrednictwo pracy i pomoc w znalezieniu pracy. 
w ciągły stan gotowości do rozwiązywania sytuacji kryzysowych, co wpływało niekorzystnie zarówno na pracę zespołów projektowych, jak również całej fundacji.

Drugim problemem, z jakim przyszło zmierzyć się badanej organizacji pozarządowej, była rekrutacja uczestników do realizowanego przedsięwzięcia. Według koordynatorów, problem wynikał z niechęci wybranej grupy, do której adresowany był projekt, do udziału w projekcie. Szczegółowa rozmowa z kierownikami umożliwiła wyciagnięcie daleko idących wniosków. Po pierwsze, okres, jaki upływał pomiędzy złożeniem wniosku o dofinansowanie a rozpoczęciem jego realizacji, to średnio 6 miesięcy. W tym czasie osoby, które były badane na etapie planowania projektu, traciły zainteresowanie nim po pół roku ze względu na zmianę swojej sytuacji życiowej lub zawodowej. Równocześnie pojawiały się na rynku inne, konkurencyjne przedsięwzięcia, realizowane przez powiatowe urzędy pracy lub ośrodki pomocy społecznej, które „przejmowały” zrekrutowaną na etapie planowania grupę docelową. Sytuacja zaogniała się jeszcze bardziej, gdy - w wyniku zastosowania kryteriów strategicznych, za które projektodawcy otrzymywali dodatkowe punkty - do grupy docelowej (zawężonej dodatkowo, np.: geograficznie lub wiekowo) adresowało swoje projekty kilka podmiotów. Wówczas ryzyko niezebrania założonej grupy stawało się na tyle realne, że projektodawcy byli zmuszeni albo do znacznego przedłużenia rekrutacji, w najlepszym razie, albo do zmiany opisu grupy docelowej i ponownej weryfikacji założeń projektowych, albo do rezygnacji z dofinansowania (w najgorszym wypadku). Naturalnie nie bez znaczenia - jak we wszystkich projektach realizowanych z EFS - był czynnik ludzki zarówno po stronie realizatora, jak uczestnika projektu. Niedostateczne kompetencje pracownika odpowiedzialnego za rekrutację oraz zastosowanie nieadekwatnych - do danej grupy docelowej - kanałów informacji o przedsięwzięciu również mogły rzutować na przebieg procesu naboru do projektu.

\section{Rekomendacje dla badanej organizacji}

Analiza powyższych projektów pozwoliła na sformułowanie rekomendacji dla zbadanej fundacji w zakresie zarządzania projektami. Metodyki PRINCE2 i PMBOK uzupełniają się wzajemnie, nie stanowiąc dla siebie konkurencji. Dlatego wdrożenie przez organizację dodatkowych - obok metodyki PCM - rozwiązań, zapożyczonych z już istniejących, wybranych metodyk zarządzania projektem, przełoży się na realne korzyści i minimalizowanie ryzyka w realizacji projektów ze źródeł EFS. Choć zaproponowane rozwiązania odpowiadają na zdiagnozowane problemy, to - ze względu na specyfikę projektów unijnych, jak również odmienny charakter projektodawcy - stanowią jedynie propozycję do implementacji w zarządzaniu.

1. Powołanie w strukturach organizacji Komitetu Sterującego (zapożyczonego z metodyki PRINCE2), którego zadaniem byłby strategiczny nadzór nad prawidłowym przebiegiem projektów (pod red. Trockiego, 2015, s. 320). 
Dodatkowym, proponowanym działaniem, które przeciwdziałałoby sytuacjom problemowym, bądź w porę reagowało na nie, byłoby powołanie wewnętrznej komórki lub specjalisty, odpowiedzialnego za wewnętrzną kontrolę projektów w organizacji. Proponowane działania ewaluacyjno-kontrolne miałyby charakter cykliczny (np: raz na kwartał) i dotyczyłyby wszystkich realizowanych projektów ${ }^{33}$. Warto również zastanowić się nad wyznaczeniem kamieni milowych. Technika ta ma za zadanie określić postęp projektu i stanowi przydatne narzędzie monitorowania projektu ${ }^{34}$.

2. Przeprowadzenie ponownej, rzetelnej analizy interesariuszy projektu i proponowanych działań bezpośrednio po otrzymaniu decyzji o dofinansowaniu, lecz jeszcze przed rozpoczęciem wdrażania projektu. Miałoby to zapobiec przeciąganiu się procesu rekrutacji, opóźnień w realizacji, a także ograniczyć niebezpieczeństwo niepełnych grup w prowadzonych naborach do udziału w projekcie. Pomocne może być również wyznaczenie ścieżki krytycznej (Critical Path Method), która stanowi ciąg zadań o łącznym, możliwie najdłuższym czasie trwania. Podstawą jej wyznaczania są wzajemne relacje pomiędzy zadaniami. Technika ta umożliwia również określenie najwcześniejszego, możliwego terminu zakończenia projektu. Planowanie przy pomocy ścieżki krytycznej wskazuje zarządowi organizacji na najważniejsze zadania, niezbędne do zakończenia całego przedsięwzięcia w terminie ${ }^{35}$.

3. Stworzenie sieci działań (zapożyczonej z metodyki PMBOK), która umożliwi budowę sieci projektu, a tym samym ułatwi jego wdrażanie. Większość projektów - szczególnie w fazie początkowej - ma zbliżony przebieg i wymagana jest realizacja tych samych lub podobnych działań. Jeszcze na etapie planowania można dokonać podziału na działania, które należy podjaćc: przed, w trakcie i po zakończeniu realizacji projektu. PMBOK to siatka rozwiązań projektowych i zarazem wskazówka, czym należy w ramach projektu się zająć, aby osiągnąć założone cele ${ }^{36}$. Jej zastosowanie zmniejszy tym samym ryzyko niepowodzenia projektu i ujednolici prace zespołów projektowych.

33 Takie rozwiązanie adresowane jest przede wszystkim do tych podmiotów non profit, które realizują równocześnie kilka i więcej projektów, lub projekty są większe, charakteryzują się wysokim stopniem skomplikowania albo dużym budżetem.

36 Stworzona w ten sposób sieć będzie stanowiła prosty schemat, wg którego należy wdrażać projekt, co ułatwi jego kontrolę zarówno kierownictwu organizacji i Komitetowi Sterującemu, jak również zarządzanie nim przez koordynatora i ewentualne przekazanie obowiązków jego następcy. 
Fakultatywnymi działaniami, wspomagającymi tak zmodyfikowaną metodykę zarządzania PCM, mogą być:

4. Szkolenia dla nowych pracowników i cykliczne szkolenia zespołów projektowych, dotyczące wybranych metodyk zarządzania projektami, co zmniejszy ryzyko powstania oporu przed zmianą oraz uświadomi istotę wdrażanej metody lub metodyki zarządzania projektem, współfinansowanym ze źródeł EFS.

5. Ujednolicona ( $w$ miarę możliwości) dokumentacja projektowa, co byłoby zgodne ze standardami PRINCE2 ${ }^{37}$.

\section{Podsumowanie}

W artykule zostały zaprezentowane metodyki zarządzania projektami ze źródeł Europejskiego Funduszu Społecznego, najczęściej stosowane przez organizacje pozarządowe. Wskazano na typy projektów, realizowane przez sektor non profit w obecnej perspektywie finansowej 2014-2020, a także dokonano krótkiej charakterystyki każdej z zaprezentowanych metodyk. Ponadto, na podstawie badania własnego $\mathrm{w}$ fundacji, będącej beneficjentem środków pomocowych z EFS w poprzednim okresie programowania, sformułowano zalecenia dla analizowanego podmiotu. Mogą one również stanowić rekomendacje dla wszystkich projektodawców w zakresie efektywniejszego zarządzania projektami i zostać wykorzystane w obecnie realizowanych przedsięwzięciach ze środków EFS.

Autorka pragnie zwrócić uwagę, że wskazane rozwiązania nie będą stanowiły gotowego narzędzia do implementacji dla każdej z organizacji. Są jedynie propozycją do ich rozważenia, a - być może - również do wdrożenia. Celem niniejszego artykułu jest zwrócenie uwagi sektora pozarządowego na różnorodność dostępnych metodyk zarządzania projektami i obowiązku kierownictwa do modyfikacji istniejących rozwiązań, tak, aby zostały dostosowane do potrzeb konkretnej organizacji.

\section{BIBLIOGRAFIA}

[1] A guide to the project management body of knowledge, 2012, Fifth Edition, PMI, USA.

[2] Adamiak P., Charycka B., Gumkowska M., 2016, Kondycja sektora organizacji pozarzadowych $w$ Polsce 2015. Raport z badań, Stowarzyszenie Klon/Jawor, Warszawa.

[3] Stabry£a A. I Trzcieniecki J. (red.), 1988, Doskonalenie struktury organizacyjnej, Wydawnictwo Akademii Ekonomicznej w Krakowie, Kraków.

37 Każdy z dokumentów wymaganych przez metodykę PRINCE2 jest dostarczony jako szablon, który zawiera m.in. wymagane: metrykę i pola informacyjne, co ma zapewnić kompletność, standaryzację oraz przejrzystość dokumentacji projektowej. 
[4] Gumkowska M., Herbst J., 2006, Podstawowe fakty o organizacjach pozarządowych. Raport $z$ badania 2006, Stowarzyszenie Klon/Jawor, Warszawa.

[5] Martyniak Z., 1999, Metody organizacji i zarządzania, Wydawnictwo Akadami Ekonomicznej w Krakowie, Kraków.

[6] Nicholas J.M., Steyn H., 2012, Zarzadzanie projektami. Zastosowania w biznesie, inżynierii i nowoczesnych technologiach, Wolters Kluwer Sp. z o.o., Warszawa.

[7] Projekty innowacyjne. Poradnik dla projektodawców Programu Operacyjnego Kapitat Ludzki, 2011, Ministerstwo Rozwoju Regionalnego, Warszawa.

[8] SzPitler A., 2014, Pojęcie projektu i jego rola $w$ zarządzaniu, [w:] Sadkowska J. i Chmielewski M. (red.), Zarządzanie projektami. Wybrane aspekty, Gdańsk.

[9] Trocki M., Grucza K., Ogonek K., 2003, Zarzadzanie projektami, Polskie Wydawnictwo Ekonomiczne, Warszawa.

[10] Wysocki R.K., 2013, Efektywne zarzadzanie projektami. Tradycyjne, zwinne, ekstremalne, Wydawnictwo HELION, Gliwice.

[11] Zarządzanie cyklem projektu, 2006, Urząd Komitetu Integracji Europejskiej, Warszawa.

[12] Janasz K., WiśniewsKa J. (red.), 2014, Zarządzanie projektami w organizacji, Difin SA, Warszawa.

[13] Trocki M. i Grucza B. (red.), 2007, Zarzadzanie projektem europejskim, Polskie Wydawnictwo Ekonomiczne, Warszawa.

[14] Trоскі M. (red.), 2015, Zarzadzanie projektem europejskim, Polskie Wydawnictwo Ekonomiczne, Warszawa.

[15] Żyro T., 2006, Wstęp do politologii, Wydawnictwo Naukowe PWN, Warszawa.

\section{NETOGRAFIA}

[16] Drucker P., 1994, The Age of Social Transformation, The Atlantic Monthly, http://www.providersedge.com/docs/leadership_articles/age_of_social_transformation.pdf (29.11.2016).

[17] EUR-Lex Baza aktów prawnych Unii Europejskiej, Traktat ustanawiający Europejską Wspólnotę Gospodarcza $z$ dnia 25.03.1957, http://eur-lex.europa.eu/legal-content/DE/TXT/PDF/?uri=CELEX:11957E/TXT\&from=PL (26.11.2016).

[18] Ha£as M, 2013, Prosto wytłumaczona: Ścieżka Krytyczna, http://4pm.pl/artykuly/prosto-wytlumaczona-sciezka-krytyczna (29.11.2016).

[19] Kraszewska M., 2013, Zwinne metodyki zarzadzania projektami, http://www.ipma.pl/informacje-prasowe/zwinne-metodyki-zarzadzania-projektami_n2050 (22.11.2016).

[20] Ministerstwo Rozwoju, 2015, Przeczytaj o Europejskim Funduszu Społecznym, Ministerstwo Rozwoju, http://www.funduszeeuropejskie.gov.pl/strony/o-funduszach/europejski-fundusz-spoleczny/przeczytaj-o-europejskim-funduszu-spolecznym/ (28.11.2016).

[21] What is PRINCE2?, https://www.prince2.com/eur/what-is-prince2 (26.11.2016).

[22] Zarządzanie w projekcie, http://www.projekty.4innovations.pl/ (30.11.2016). 